Article

\title{
The Political Ecology of Chinese Large Dams in Cambodia: Implications, Challenges and Lessons Learnt from the Kamchay Dam
}

\author{
Giuseppina Siciliano ${ }^{1, *}$, Frauke Urban ${ }^{1}$, May Tan-Mullins ${ }^{2}$, Lonn Pichdara ${ }^{3,4}$ and Sour Kim ${ }^{3}$ \\ 1 Centre for Development, Environment and Policy CeDEP, School of Oriental and African Studies SOAS, \\ University of London, 36 Gordon Square, London WC1H0PD, UK; f.urban@soas.ac.uk \\ 2 School of International Studies, Institute of Asia and Pacific Studies, The University of Nottingham, \\ 199 Taikang East Road, AB313, Ningbo 315100, China; may.tan-mullins@nottingham.edu.cn \\ 3 Cambodia Development Resource Institute (CDRI), 56 Street 315, Tuol Kork, Phnom Penh 12152, Cambodia; \\ lonn.pichdara@gmail.com (L.P.); sourkim@outlook.com (S.K.) \\ 4 Graduate School of Bioresource and Bioenvironmental Sciences, Kyushu University, 6-10-1 Hakozaki, \\ Higashi-ku, Fukuoka 812-8581, Japan \\ * Correspondence: gs45@soas.ac.uk; Tel.: +44-75-9774-5708
}

Academic Editor: Athanasios Loukas

Received: 7 June 2016; Accepted: 1 September 2016; Published: 18 September 2016

\begin{abstract}
Given the opportunities offered by foreign investment in energy infrastructure mostly by Chinese firms, the Government of Cambodia is giving high priority to developing hydropower resources for reducing energy poverty and powering economic growth. Using a "Political ecology of the Asian drivers" framework, this paper assesses China's involvement in the development of large dams' in Cambodia and its impacts on the access of natural resources such as water and energy by dam builders, local communities and the government. This analysis is based on 61 interviews and 10 focus group discussions with affected communities, institutional actors, Chinese dam builders and financiers in relation to the first large Chinese dam built in Cambodia: the Kamchay dam. Based on the results of the analysis this paper makes recommendations on how to improve the planning, implementation and governance of future large dams in Cambodia.
\end{abstract}

Keywords: hydropower; political ecology; social and environmental impacts; Cambodia; China

\section{Introduction}

This paper aims to explore the political ecology of Chinese large hydropower dams in Cambodia, particularly the implications, challenges and lessons learnt from the Kamchay dam, Cambodia's first dam.

Cambodia's electricity production is far below the country needs and imports exceed by far the internal production [1], therefore the country relies heavily on energy and electricity imports, mainly from neighbouring countries, such as Thailand and Vietnam. Cambodia has also some of the highest electricity costs in the world [2,3].

Given the opportunities offered by the country's topography of mountain valleys, fast-flowing streams and powerful rivers, as well as foreign investment in energy infrastructure mostly by Chinese firms, the Government of Cambodia is giving high priority to developing hydropower resources with the aim of providing energy access, reducing energy poverty, powering economic growth, increasing energy security and reducing electricity prices [4]. The Ministry of Mines and Energy (MME) and the Mekong River Commission (MRC) estimate that the country's technically exploitable hydropower capability is about 10,000 MW [1,5]. Ten percent of the potential was under construction in 2011, and an additional $2200 \mathrm{MW}$ is in planning [6]. 
Hydropower dams are currently undergoing a renaissance as low carbon energy alternatives to fossil fuels and due to their possible contribution to mitigating climate change. Yet, they are highly vulnerable to climatic changes [7]. An interview with an official at the International Energy Agency (IEA) in Paris (anonymous, Paris, France, 23 June 2015), revealed hydropower is viewed positively as one of the main mitigation strategies for climate change at a global level. Other benefits of large hydropower dams include flood control, technological progress and job creation [8]. However, large hydropower dams, despite their possible developmental and carbon reduction contributions, are accompanied by huge economic costs $[9,10]$, profound negative environmental changes [11-13] and social issues [14-16].

At the forefront of the renaissance of large hydropower dams are the Chinese as the world's largest dam builder. Sinohydro, a Chinese state-owned enterprise (SOE), is leading the global hydropower sector in terms of number and size of dams built, investment sums and global coverage. While China has a long history of domestic dam-building, recent developments have led to Chinese overseas projects, particularly in low and middle income countries in Asia and Africa $[17,18]$ of which $38 \%$ are built in Southeast Asia, including in Cambodia [19].

While the government and its development partners focus on the benefits of hydropower production, the risks associated with dam construction are less well understood among policy and decision-makers in countries like Cambodia. Environmental and socio-economic impacts of large dams are inevitable. The interrelated dynamics between human populations and the environment are severely affected by the construction of big infrastructure projects such as dams [20]. However, the severity of adverse impacts depends to some extent on mitigation strategies and how they are being implemented by dam builders and local governments to reduce the environmental and social impacts on affected communities. This paper aims to discuss the social, environmental and economic implications and challenges at the national and local levels from Cambodia's first large hydropower dam, the Kamchay dam. Moreover, the paper discusses the governance arrangements between Chinese dam builders and financiers, who funded and built the Kamchay dam, and the Cambodian government in terms of compensation, environmental impact assessment (EIA) procedures, mitigation and consultations regarding the development and operation of the Kamchay dam. For assessing these issues the analysis is based on the "Political Ecology of the Asian Drivers" framework, which is a combination of the Political Ecology framework [21-25] and the Asian Drivers framework [26-28]. This framework is used to assess China's involvement as a rising power in the development of large dams' development in Cambodia and its impacts on the access and use of natural resources such as water and energy by dam builders, local communities and the government. While the majority of the studies on large dams' impacts focus on the impacts at an aggregated level, such as the county level [13]; on multidisciplinary approaches to model the costs and benefits of dams' construction [11]; or on the local impacts of dams built by Chinese builders in China [13], this paper looks at the impacts experienced by affected communities at the village level and at Chinese engagement in large dams development overseas. Moreover, with respect to other studies published by the authors on China's engagement in large dams in Cambodia [29-31] this paper looks for the first time from a Political ecology of the Asian Drivers Perspective at how different channels of interactions between Chinese dam builders and Cambodian authorities have had an influence in the altered human-environment interactions and on the distribution of costs and benefits between different beneficiaries. The analysis is based on extensive interviews and focus group discussions with affected communities, institutional actors, Chinese dam builders and financiers. Based on the results of the analysis this paper makes recommendations on how to improve the planning, implementation and governance of future development of large dams in Cambodia.

Section 2 discusses the methodology, Section 3 presents the results, Section 4 discusses the findings from the perspective of the Political Ecology of the Asian Drivers and Section 5 concludes the paper. 


\section{Materials and Methods}

\subsection{Case Study Selection: The Kamchay Dam}

The Kamchay dam is Cambodia's first large hydropower dam, with an installed capacity of 194 MW (Table 1). The Kamchay deal was strongly supported and driven forward by the Cambodian Prime Minister, Hun Sen. The project was the first of a series of dams financed and built by Chinese dam-builders in Cambodia. It was regarded by the Cambodian government as a stepping stone for attracting major investment from powerful China to impoverished Cambodia.

Sinohydro started building the Kamchay Dam in Kampot Province, Southern Cambodia in 2006. The dam started operation in late 2011. The Department of Environment in Kampot province claims that the dam can supply up to 60\% of Cambodia's energy demand, at least in the wet season [32]. The dam costs an estimated US\$311 million and is financed by China ExIm Bank as part of a US\$600 million aid, trade, and investment package to Cambodia [33]. The dam agreement is based on a BOT (Build, Operate, Transfer) contract which includes four years of construction and 40 years of operation, which also means that the dam will belong to Chinese dam-builder Sinohydro for 44 years from the date of the start of construction and will then be transferred to the Cambodian government in 2050 .

The Kamchay dam is located in Bokor National Park. It is evergreen, tropical forest, with some mixed bamboo forest in a hilly area with elevations up to around $1000 \mathrm{~m}$, surrounded by the Cardamom Mountains, part of the Elephant Mountain Range. The area is famous for its rich biodiversity, hosting 39 mammal species -including 10 endangered species mentioned on the IUCN Red List, 68 bird species, 23 reptile species and 192 fish species [34,35].

Table 1. Technical details of Kamchay dam.

\begin{tabular}{cc}
\hline Technical Aspects & Description \\
\hline Type of dam: hydropower & rolling compacted concrete gravity dam \\
\hline Reservoir capacity $\left(\right.$ billion $\left.\mathrm{m}^{3}\right)$ & 0.68 \\
\hline Reservoir surface area $\left(\mathrm{km}^{2}\right)$ & 20 \\
\hline Purpose & power generation (electricity) \\
\hline Generating capacity (MW) & 194 \\
\hline Height (m) & 568 \\
\hline Length (m) & 311 million \\
\hline Cost (US\$) & 498 \\
\hline Average annual energy & Kampot, Phnom Penh and Preah \\
generation capacity (GWh) & Sihanouk Province \\
\hline Electricity supply & Build, Operate, Transfer contract (BOT) \\
\hline Type of contract & Note: Reference: [36].
\end{tabular}

The reservoir has led to the flooding of 2291 hectares of protected forest in Bokor National Park, including roads and infrastructure [32].

During fieldwork we interviewed the local population in five different affected villages: Mortpeam, Bat Kbal Damrei, Ou Touch, Snam Prampir, and Tvi Khang Cheung. These villages are located downstream of the dam and rely mainly on fruit tree plantations, rice fields, bamboo collection, tourism, fishing and non-timber forest products (NTFPs) collection. In Snam Prampir villagers are mainly fruit sellers to tourists, bamboo collectors, and firewood collectors; in Tvi Khang Cheung and $\mathrm{Ou}$ Touch villagers are highly dependent on NTFPs collection, especially bamboo; villagers in 
Mortpeam and Bat Kbal Damrei are mainly durian growers [37]. Fishing activities represent another supplementary source of income and subsistence for almost all the villages interviewed, however to a less extent compared with the other activities mentioned above [32].

\subsection{Theoretical Framework}

The majority of earlier work on China's engagement with low and middle income countries has been speculative [38], economistic [39], and Africa focused [40,41]. Crucially these studies have largely ignored the environmental consequences of China's internationalisation. Understanding a complex set of international actors, interdependencies and ecological impacts necessitates a broad theoretical framework [42]. This research uses the conceptual framework of the 'Political Ecology of the Asian Drivers'. The political ecology framework [25] is used as a basis for analysing the implications caused by the varied forms of control over the access to natural resources such as water and energy [22-24] to highlight governance issues and the unequal distribution of costs and benefits associated with environmental change brought by human intervention, in this case by large infrastructure development. Large energy infrastructures such as dams have profound effects on the society-environment relationships. Large dams are most of the time associated with land enclosures for infrastructure development, resettlement of the local population and environmental impacts. Power relations between different actors embedded in social and political interests of large dams' construction can influence society-environment interactions in different ways, such as access to resources, assessment and mitigation of the impacts. To analyse power relations and their influence on society-environment interactions associated with large dams development, we combine the political ecology framework with the "Asian Drivers" framework. The Asian Drivers framework developed by Humphrey and Messner [26], Schmitz [27], and Kaplinsky and Messner [28] assesses China's direct and indirect impacts as a Rising Power and its channels of interaction with low and middle income countries. In each of these channels-aid, trade, investment, global governance, individuals/migrants and environment-there will be a mixture of complementary and competitive economic impacts and positive and negative impacts in relation to society and the environment [28]. Urban et al. [30] advanced the Asian Drivers Framework further by addressing the motives, actors and beneficiaries in addition to impacts to analyse how, why and with which impacts Chinese actors engage in low and middle income countries (Table 2).

Table 2. The Asian Drivers framework applied to the study of large dams in Cambodia.

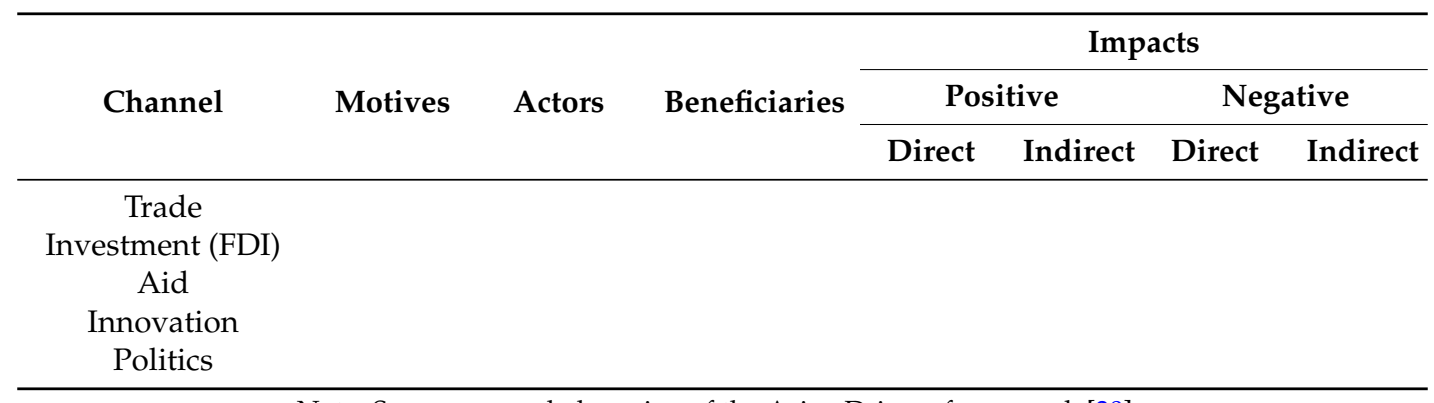

Note: Source: amended version of the Asian Drivers framework [30].

To assess the impacts associated with environmental change brought by large dam development in Cambodia, and to discuss power relations in terms of the control over the access to natural resources by different actors, we conducted a qualitative analysis of semi structured interviews carried out with affected communities, Chinese builders, government representatives and other actors as specified in Sections 2.3 and 2.4 . 


\subsection{Methods: Fieldwork}

The methodology includes detailed fieldwork at the dam site and in China. We conducted 61 interviews and 10 focus group discussions: 19 key informant interviews with institutional actors who had an involvement in the Kamchay dam construction; 18 interviews with Chinese dam-builders and financiers; 24 interviews with affected community members and their community chiefs and 10 focus group discussions (interviews and focus group discussions have been carried out in Khmer in the case of Cambodian interviewees and in Chinese in the case of Chinese interviewees). For the institutional interviews, we undertook semi-structured interviews with policy-makers, NGOs and academics. This included representatives such as the Department of Hydropower, Ministry of Industry, Mines and Energy, Ministry of Water Resources, Electricity Authority of Cambodia, the Kampot Provincial Department of Environment, as well NGO Forum on Cambodia and the International Union for Conservation of Nature (IUCN). These actors were interviewed on their perceptions of the socioeconomic and environmental impacts of the dam, governance issues, political and economic implications. On the Chinese side, semi-structured interviews were conducted with dam-builders and financiers such as Sinohydro, ExIm Bank and government officials from authorities like the Ministry for Water Resources, the Ministry of Finance and Commerce to investigate dam contract issues, governance arrangements, economic and political implications and their understanding of the social and environmental impacts of the dam. For the community fieldwork, we carried out 2 focus groups in each of the 5 affected villages selected (Mortpeam, Bat Kbal Damrei, Ou Touch, Snam Prampir, and Tvi Khang Cheung, selected in collaboration with the village chiefs and based on the diversity of their main livelihoods, distinguishing among bamboo collectors, firewood collectors, durian growers and fruit sellers) around the Kamchay dam site using semi-structured open-ended questions. In addition we conducted 22 individual semi-structured interviews with community members and with the village chiefs (6 with woman and 16 with men) (Table 3).

Table 3. Interview setup.

\begin{tabular}{cccc}
\hline Targets & Methods & No. of Interviews & Further Details \\
\hline $\begin{array}{c}\text { Affected local communities at } \\
\text { Kamchay Dam site: (Bat Kbal } \\
\text { Damrei, Mortpeam, Ou Touch, } \\
\text { Snam Prampir, Tvi Khang Cheung) }\end{array}$ & Focus groups & $\begin{array}{c}10 \text { focus group } \\
\text { discussions }\end{array}$ & $\begin{array}{c}50 \% \text { women; } \\
50 \% \text { men }\end{array}$ \\
\hline $\begin{array}{c}\text { Affected individuals from } \\
\text { local communities }\end{array}$ & Semi-structured & 24 & 19 \\
\hline Institutional actors & $\begin{array}{c}\text { Semi-structured } \\
\text { interviews }\end{array}$ & $\begin{array}{c}\text { National/local } \\
\text { gevernment, NGOs }\end{array}$ \\
\hline Chinese actors & 18 & $\begin{array}{c}\text { Sinohydro, } \\
\text { regulators and } \\
\text { financiers }\end{array}$ \\
\hline
\end{tabular}

\subsection{Data Analysis}

We analysed the transcribed, qualitative data by categorising and coding the sources as a means of comparing and contrasting interpretations of events [43]. We used the Nvivo 10 software to code the interviews with affected communities and focus group consultation data. These were analysed using narrative analysis [44] rather than conventional 'code and retrieve' since the former allows for more layers of embodied meaning to be revealed by including narrative style to compare similar findings and flag up any differences [45]. More specifically, the interviews and focus group discussions were coded according to themes and sub-themes. The broad themes were divided in social, environmental, economic, political and technological perspectives. Under each of these broad themes we coded very specific sub-themes that were based on the fieldwork information (e.g., livelihood impacts, 
environmental impacts, EIA procedures etc.). This resulted in 2704 coded references, thus enabling us to see a pattern and understand the most important issues of this fieldwork. Based on the coded references using Nvivo 10 we performed a word frequency analysis to list the most frequently occurring words in the coded interviews in relation to the positive and negative impacts of the dam construction perceived by local community members and village chiefs. The most frequently occurring words were related to livelihoods and access to resources, such as land, energy, water, forest products, and food, as explained in Section 3.

\section{Results}

This section assesses the negative and positive impacts of the Kamchay dam construction and its implications over the access and use of natural resources such as water and energy by local communities. This analysis is linked to the Political Ecology of the Asian Drivers framework by assessing the altered society-environment relationships associated with changes in the physical environment caused by the construction of the Kamchay dam.

\subsection{Impacts on Access to Natural Resources}

According to the word frequency analysis the main sources of concern of the affected communities are the limited access to electricity and to natural resources, such as non-timber forest products (NTFPs) (i.e., bamboo, firewood, water, fish, land) (Table 4).

Table 4. Word frequency analysis for access to resources.

\begin{tabular}{cccc}
\hline Word & Count & Weighted $\%$ & Quote Reference (QR) \\
\hline electricity & 227 & 5.15 & $\mathrm{~A}$ \\
bamboo & 130 & 2.95 & $\mathrm{~B}$ \\
fish & 122 & 2.77 & $\mathrm{C}$ \\
water & 81 & 1.84 & $\mathrm{D}$ \\
land & 38 & 0.86 & $\mathrm{E}$ \\
company (i.e., Sinohydro) & 31 & 0.70 & $\mathrm{~F}$ \\
reservoir & 30 & 0.68 & $\mathrm{G}$ \\
catch & 27 & 0.61 & $\mathrm{H}$ \\
mountain & 27 & 0.61 & $\mathrm{I}$ \\
upstream & 25 & 0.57 & $\mathrm{~L}$ \\
firewood & 24 & 0.54 & $\mathrm{M}$ \\
access & 21 & 0.48 & $\mathrm{~N}$ \\
road & 21 & 0.48 & $\mathrm{O}$ \\
\hline
\end{tabular}

Notes: count refers to the number of times that the word occurs within the project items searched, in this case access to natural resources; the weighted percentage indicates the frequency of the word relative to the total words counted; the quote reference indicates the correspondence between selected quotes reported in the text and the word frequency analysis.

\subsubsection{Access to Non-Timber Forest Products}

The interviewees reported that access to non-timber forest products (NTFPs), such as bamboo and firewood, but also access to fish downstream has dramatically decreased after the construction of the dam. The dam has flooded 2291 ha of land and forest in Bokor National Park, which was previously used by the local communities for the collection of NTFPs. As indicated in the quote below, while the main bamboo collection area is flooded, the villagers have found another bamboo forest site that is further away and to access that area they have to cross the reservoir by using motorized boats.

"There is no bamboo near here; however, there are many bamboos in the area behind the dam reservoir. We need to use rafts to carry bamboo back home" (quote from FGD with female in Ou Touch-QR: B). 
Moreover, they reported that occasionally Sinohydro puts a ban on bamboo collection and closes off access to the area completely: "Before the construction of the dam, they (Sinohydro) never banned the bamboo ground, but now they catch our boat. And if we do not have a boat, we cannot go to cut bamboo" (quote from FGD with female in Mortpeam).

Villagers reported they are only able to collect a low quantity of bamboos since the dam was built. This is because the old bamboo area has been flooded and the new bamboo area is far away and difficult to access. "We collect less bamboo and spend more than before"; and "We spend on petrol, raft and truck fees" (quotes from FGD with men in Ou Touch; QR: B).

The inundation of the forest area in Bokor National Park has also negatively impacted on firewood collectors and fruit collectors. Firewood collectors reported that they have been banned by Sinohydro from accessing the dam area to avoid the illegal collection of timber from the dam site. Moreover, fruit collectors reported that due to the clearance of the forest by Sinohydro many fruit trees were cut as well, impacting negatively the income of fruit sellers. "Now we are not allowed to access the site for firewood collection. Our request is that the company should allow people to collect firewood, and let them farm and collect resources on the mountains" (quote from FGD with male in Snam Prampir; QR: F, M); and "There is not much firewood because we don't have many forests anymore" (quote from woman respondent in Mortpeam; QR: M).

\subsubsection{Access to Fish}

Access to fish is also a source of concern of the affected communities. Villagers reported that before the construction of the dam in the rainy season the flow of the water from the mountain to the stream was abundant and they were able to catch a lot of fish. The water flow from the dam is now regulated by Sinohydro, and villagers complain that the flow is not enough, therefore the presence of the fish in the stream has decreased:

"We could catch from four to five kilograms per day, in the rainy season before the dam was built. After the dam construction, we can catch only one or two fish per day for providing a meal for our own family"; and "Now, fishermen do not fish anymore; they buy fish from others" (quotes from male respondents in Mortpeam; QR: C, H).

\subsubsection{Access to Land}

The loss of land due to construction works is also a source of concern for some of the villagers. Villagers have complained mainly in relation to the compensation they received by Sinohydro, which was only three dollars per square meter of lost land in comparison to the five dollars initially promised. Compensation issues have been managed only by Sinohydro's officials, who visited the affected communities and decided the amount to be provided for the lost land and crops.

Moreover, not all the villagers received compensation for the lost land since they were only paid for lost crops.

"I had rice land impacts". "They (Sinohydro) compensated three dollars per square meters". "The Chinese company promised to compensate five dollars, so people went to complain at the district. Although we tried to complain, we still only got three dollars per square meter" (quotes from FGD with women in Mortpeam; QR: E, F). "I had farmland impact, but they did not compensate for the land, they only compensated for the lost crops" (quotes from FGD with men in Mortpeam; QR: E).

\subsubsection{Access to Electricity}

Access to electricity is also one of the most important concerns of the affected communities in the dam area. As reported by the villagers interviewed there are houses located close to the dam that do not have access to electricity yet: "Most of the houses do not use electricity, they use kerosene lamp" and "[...] the price of electricity is too expensive" (quote from FGD with Female in Mortpeam; QR: C). 
One of the main reasons for the lack of electricity in some of the houses is that the electricity used at the dam site area is not coming from the Kamchay dam but imported from neighbour countries, mainly Vietnam, and provided to the villagers by private companies at unaffordable prices for the poorest families in the area:

"This electricity is from Vietnam, from a private enterprise. We are wondering why we live next to the dam, but the price of electricity is more expensive than other villages in the province" (quote from FGD with men in Bat Kbal Damrei; QR: C). Most of the electricity generated at the Kamchay dam is being used in Phnom Penh, as the capital needs power to generate economic growth. The beneficiaries of the dam are therefore not the people who are affected by it on a daily basis; instead many of them are being left without electricity access. Nevertheless, the price of electricity after the construction of the dam has been reduced from 1800 Riel per $\mathrm{kWh}$ to 920 Riel per $\mathrm{kWh}$. This is however higher than the initially mentioned 500-600 Riel per kWh that was promised by Sinohydro, as indicated in the quote below: "When they inaugurated the dam, the price of electricity was decreased, and the Chinese company promised that they will try to reduce the price of electricity to six hundred Riel per kilowatt-hour" (quote from FGD with female in Snam Prampir; QR: C); and "Electricity costs nine hundred and twenty Riel per kilowatt-hour. At the Rom Deng village the price of electricity is only six hundred Riel per kilowatt-hour. We live in the same province but the electricity imported from Vietnam has different prices" (quote from FGD with female in Tvi Khang Cheung; QR: C). Moreover, even though electricity has become more affordable many people do not have the financial means to connect to the grid as it requires a connection fee of US\$160 per household, as the villagers report. The analysis above showed how the society-environment relationship, which is central to the political ecology analysis, has changed since the dam construction as access to natural resources such as forest products and fish is more limited. The analysis above also highlights the role of China as a rising power, by highlighting the role Sinohydro plays for providing access to the bamboo forest area and by addressing the issue of electricity prices.

\subsection{Livelihood Changes and Impacts}

Table 5 shows the most frequently occurring words in the interviews and focus group discussions to describe the livelihoods' changes and impacts they experienced.

Table 5. Word frequency analysis for livelihoods' changes and impacts.

\begin{tabular}{cccc}
\hline Word & Count & Weighted \% & Quote Reference (QR) \\
\hline bamboo & 44 & 3.13 & $\mathrm{P}$ \\
livelihood & 33 & 2.35 & $\mathrm{Q}$ \\
difficult & 24 & 1.71 & $\mathrm{R}$ \\
sell & 24 & 1.71 & $\mathrm{~S}$ \\
durian & 23 & 1.64 & $\mathrm{~T}$ \\
fruit & 19 & 1.35 & $\mathrm{U}$ \\
work & 16 & 1.14 & $\mathrm{~V}$ \\
road & 13 & 0.93 & $\mathrm{~W}$ \\
baskets & 11 & 0.78 & $\mathrm{X}$ \\
water & 11 & 0.78 & $\mathrm{Y}$ \\
earn & 10 & 0.71 & $\mathrm{Z}$ \\
\hline
\end{tabular}

Notes: count refers to the number of times that the word occurs within the project items searched, in this case livelihoods' changes; and the weighted percentage indicates the frequency of the word relative to the total words counted; the quote reference indicates the correspondence between selected quotes reported in the text and the word frequency analysis.

\subsubsection{Negative Livelihood Impacts on Local Communities}

The flooding of the bamboo forest and the difficult access to the forest left upstream of the reservoir have severely undermined the livelihoods of the local communities, especially for those relying on NTFPs collection, such as bamboo collectors, firewood collectors and fruit sellers. 
The bamboo collectors are the biggest group that has been adversely affected by the dam. They produce baskets from the bamboo they used to collect in the forests flooded by the dam's reservoir. The baskets are sold on the local market in Kampot town. Most of the bamboo collectors do not have any other sources of income, many of them do not own any land nor have any assets and most of them have very low literacy rates and can therefore not easily move on to more skilled jobs. As reported in the quotes below, the only livelihood alternative for the bamboo collectors is to work as construction workers; however the income they can get is not enough to support their family needs: "We have no jobs to do beside that job (collecting bamboo), and working as a construction worker cannot support our family because you can earn only around ten thousand Riel per day, and collecting bamboo we can earn more than twenty thousand Riel per day" (quote from FGD with men in Ou Touch; QR: P).

Before the dam was built, the villagers had an agreement with the Cambodian government that they would be allowed to collect bamboo in the 'multiple use zone' of Bokor National Park. They would usually start their trip in the morning, cycle up to the national park, collect the bamboo and be back home in the afternoon. In the best case, Sinohydro opens access to the smaller bamboo site that is further afield. This means the villagers can collect bamboo; however they will have to stay at the site overnight as it is far away or invest in a motorcycle and raft to access the site. This has meant that even on days when the site is open it takes the villagers longer to collect the bamboo and they will therefore earn less money over the same period of time. According to the bamboo collectors, the expenditures they have to sustain after the construction of the dam to access the forest area are almost doubled and the amount of baskets they can make is less than before: "We spend more than ten thousand Riels per each (trip). Previously, we spent only five thousand Riels and we could collect bamboo for making seven to eight baskets. Now we spend more and we get bamboo for making only two to three baskets, maximum four" (quotes from FGD with women in Ou Touch; QR: P, X, Z).

In addition, the income of fruit vendors at Tuek Chhu resort located on the Kamchay River have fallen because fewer tourists have been visiting the area since the water level and flow declined, particularly in the dry season. Local villagers reported at the interview that some people including tourists had drowned when water was suddenly released from the reservoir; water is released irregularly and without warning, as reported: "I want to request that when the Chinese firm (Sinohydro) opens the water gates, they should make a warning alarm in order to inform people downstream because there are many people dying including tourists because of the river's water rising suddenly without notice" (quote from FGD with women in Snam Prampir; QR: Y).

Women from Snam Prampir village also explained: "We cannot sell as much as we used to because the water flow is too low for tourists to bath in the river. Even on public holidays, the Chinese company does not release water. Fewer tourists have been coming here since the dam was built. Our selling reduced hugely, and now we can sell only $20 \%$ compared to what we sold before the dam" (QR: Y). The same negative impacts on livelihoods have been perceived by firewood collectors due to the ban imposed by Sinohydro to access the forest area, as reported: "it is so difficult to support our families in everyday life. If Sinohydro opens the area for collecting firewood, we can cut, sell it, and get thirty to forty thousand riels to buy rice for our children to eat" (quote from FGD with men in Snam Prampir; QR: R).

\subsubsection{Positive Livelihood Impacts on Local Communities}

However, the Kamchay dam has also had some positive effects on the affected communities, especially for durian growers. Importantly, it has helped protect some areas from annual flooding. Life is better for those living in the previously flood-prone villages, as reported: "(after the construction of the dam) There is no flood, so our durian trees are not destroyed by flood" (quote from FGD with women in Snam Prampir; QR: T); and "Since Sinohydro constructed the dam, we have had reduced flooding so that we can plant durian trees and they are not dying. Before the dam, when we had heavy rain, it used to flood our houses, especially my house was flooded three meters to four meters because my house is next to the stream" (quote from FGD with women in Mortpeam; QR: T). 


\subsection{Environmental Changes Perceived by the Local Villagers}

Environmental impacts were particularly apparent during the dam's construction, the most obvious being the flooding of land and forest in Bokor National Park [37]. Water flowing in areas downstream of the dam has been inadequate and irregular and, as many villagers and especially the fruit vendors complained, Tuek Chhu resort is attracting fewer visitors due to irregular water flow as discussed in the previous sections. Flooding of the forest and resultant changes in biodiversity around the reservoir, lower river levels and highly irregular water flows in the dry season, and blocked passage of fish to downstream fisheries have had severe consequences on the environment and the affected villages. A male respondent in Mortpeam reported: "Wild animals are now almost completely lost, and they started disappearing since the dam was constructed". There were mixed reports about impacts on fisheries resources, said to have increased in the dam reservoir, where people need to have a boat limiting their possibility to access the fish, but declined in downstream areas where people were used to go fishing [35]. However, changes in fish stocks in the reservoir and upstream are unknown since studies have not been conducted yet [35]. According to our interviews, a man from Bat Kbal Damrei village, which is located downstream noted, "Now we cannot go fishing because the dam has blocked the river and fish cannot find the passages placed in the dam to help them move downstream". Moreover, a man from Mortpeam noted that the fertility of the soil has decreased due to the reduced flooding, as a consequence he needs to use fertilizer now, as reported "With flood, the soil becomes fertile because of the sediments. Now there is no flood so the soil is not very fertile and we use some fertilizers" (quote from male respondent in Mortpeam). Water quality is also a source of concern of the local villagers. As also confirmed by other studies the decline in water quality is particularly pronounced in the dry season, when the water may have a brownish colour [34]. During an FGD with men in Bat Kbal Damrei participants reported: "After the construction of the dam, the water became dirty because of the decayed trees"; "Water doesn't flow when the dam is closed, and the water stays still. Moreover, there are the decayed trees. So, when they open the dam's gate the water is dirty and it becomes red and poisonous". Other environmental problems not mentioned by the local villagers interviewed but reported by other studies are saltwater intrusion due to the dam's vicinity to the sea, erosion and changes in sediment flow downstream that can affect the fertility of soils [32]. Moreover, it is estimated that the migration of at least 15 fish species has been severely impacted, including threatened species [34].

\section{Discussion: The Political Ecology of the Asian Drivers and the Kamchay Dam}

According to the affected communities' perceptions analysed in Section 3, the Kamchay dam construction has had profound impacts on society-environment relationships in terms of access to natural resources (i.e., water, energy, land and forest). Moreover, this section discusses the shortcomings of the Environmental Impact Assessment (EIA) procedures and environmental mitigation measures. Table 6 summaries the main aspects of the altered society-environment relationships associated with the construction of the Kamchay dam.

To understand the social and environmental implications of the Kamchay dam from a Political Ecology of the Asian Drivers perspective, it is important not only to analyse how the dam construction has altered society-environment relationships, but also the ways, i.e., channels of interactions, in which more powerful actors can enable and constraint other actors in relation to access to the physical environment [21,22]. This analysis can in turn help to identify shortcomings in relation to the governance of large dams' construction by local authorities and Chinese builders and ways to improve the sustainability of future Chinese dam construction in Cambodia, in ASEAN, particularly along the Mekong River, as well as in other low and middle income countries.

The altered relationships between humans and the environment reported in Table 6 are therefore here analysed looking at the ways different Chinese and Cambodian actors have interacted during and after the construction of the Kamchay dam (Table 7). 
Table 6. Changes of society-environment relationships associated with the Kamchay dam construction.

\begin{tabular}{cl}
\hline \multicolumn{1}{c}{ Society-Environment Relationship } & \multicolumn{1}{c}{ Implications } \\
\hline \multirow{2}{*}{ Access to natural resources and use } & $\begin{array}{l}\text { Control over the access to natural resources (water, land and forest) by dam builders } \\
\text { and Cambodian authorities through land enclosures }\end{array}$ \\
\cline { 2 - 2 } & $\begin{array}{l}\text { Diversion of the use of natural resources (land, forest, water) from local communities' } \\
\text { uses (food production and livelihoods) to energy production purposes }\end{array}$ \\
\cline { 2 - 2 } Environmental Impact Assessment (EIA) and mitigation measures & No energy access from electricity produced by the dam for affected communities \\
\cline { 2 - 2 } & Energy access for urban areas (i.e., Phnom Penh, Sihanoukville, Kampot) \\
\cline { 2 - 2 } & EIA finalised after dam's construction was completed \\
\hline
\end{tabular}

Table 7. Channels of interaction between Chinese actors and Cambodian actors, according to an amended version of the Asian Drivers framework, see Urban et al., 2011 [30].

\begin{tabular}{|c|c|c|c|c|c|c|c|}
\hline \multirow{3}{*}{ Channel } & \multirow{3}{*}{ Motives } & \multirow{3}{*}{ Actors } & \multirow{3}{*}{ Beneficiaries } & \multicolumn{4}{|c|}{ Impacts } \\
\hline & & & & \multicolumn{2}{|c|}{ Positive } & \multicolumn{2}{|r|}{ Negative } \\
\hline & & & & Direct & Indirect & Direct & Indirect \\
\hline $\begin{array}{l}\text { Trade, aid and } \\
\text { investment }\end{array}$ & $\begin{array}{l}\text { US } \$ 600 \text { million aid, trade, } \\
\text { investment package to Cambodia } \\
\text { from China ExIm Bank. Motives: } \\
\text { economic and political ties with } \\
\text { Cambodia, saturation of Chinese } \\
\text { dams sector, Chinese } \\
\text { government's Going } \\
\text { Out Strategy. }\end{array}$ & $\begin{array}{l}\text { China ExIm Bank as } \\
\text { investor, Sinohydro as } \\
\text { dam builder. }\end{array}$ & $\begin{array}{l}\text { Sinohydro as it collects } \\
\text { revenues for } 44 \text { years } \\
\text { from the Cambodian } \\
\text { government. Phnom } \\
\text { Penh, where the electricity } \\
\text { is being used. }\end{array}$ & $\begin{array}{l}\text { Long-term revenues for } \\
\text { Sinohydro; long-term } \\
\text { electricity supply for } \\
\text { Cambodia; Positive } \\
\text { local effects due to } \\
\text { partly reduced } \\
\text { flooding. }\end{array}$ & $\begin{array}{l}\text { First dam successfully } \\
\text { built, potentially opens up } \\
\text { opportunities for further } \\
\text { dam-building deals in } \\
\text { Cambodia. }\end{array}$ & $\begin{array}{l}\text { loss/decline of } \\
\text { livelihoods of } \\
\text { affected local } \\
\text { population. }\end{array}$ & $\begin{array}{l}\text { High vulnerability to } \\
\text { climate change, risks for } \\
\text { energy security. }\end{array}$ \\
\hline Innovation & $\begin{array}{l}\text { Technology transfer of } \\
\text { hydropower dams hardware } \\
\text { between China and Cambodia. } \\
\text { Economic profit by Chinese } \\
\text { dam-builders, access to modern } \\
\text { electricity generation } \\
\text { infrastructure by } \\
\text { Cambodian state. }\end{array}$ & $\begin{array}{l}\text { Sinohydro as } \\
\text { innovators, Cambodian } \\
\text { state as recipients. }\end{array}$ & $\begin{array}{l}\text { Sinohydro, Cambodian } \\
\text { state, although restricted } \\
\text { due to } 44 \text { years of } \\
\text { ownership by Sinohydro. }\end{array}$ & $\begin{array}{l}\text { Long-term access to } \\
\text { modern electricity } \\
\text { generation } \\
\text { infrastructure by } \\
\text { Cambodian state. }\end{array}$ & $\begin{array}{l}\text { Opportunities for further } \\
\text { dam-building deals in } \\
\text { Cambodia and thereby } \\
\text { access to hydropower } \\
\text { innovation in Cambodia. }\end{array}$ & $\begin{array}{l}\text { loss/decline of } \\
\text { livelihoods of } \\
\text { affected local } \\
\text { population. }\end{array}$ & $\begin{array}{l}\text { Transfer of hardware but } \\
\text { lack of knowledge transfer } \\
\text { in terms of maintenance and } \\
\text { operation of the dam. } \\
\text { Capacity in innovation in } \\
\text { dam technology is limited } \\
\text { and mostly remains with the } \\
\text { Chinese dam-builders. }\end{array}$ \\
\hline
\end{tabular}


Table 7. Cont.

\begin{tabular}{|c|c|c|c|c|c|c|c|}
\hline \multirow{3}{*}{ Channel } & \multirow{3}{*}{ Motives } & \multirow{3}{*}{ Actors } & \multirow{3}{*}{ Beneficiaries } & \multicolumn{4}{|c|}{ Impacts } \\
\hline & & & & \multicolumn{2}{|c|}{ Positive } & \multicolumn{2}{|c|}{ Negative } \\
\hline & & & & Direct & Indirect & Direct & Indirect \\
\hline \multirow{2}{*}{$\begin{array}{l}\text { Politics and } \\
\text { governance }\end{array}$} & $\begin{array}{l}\text { Close political ties between } \\
\text { China and Cambodian. This } \\
\text { ensures China is a powerful } \\
\text { political ally for Cambodia and it } \\
\text { ensures China receives support } \\
\text { from Cambodia for its foreign } \\
\text { policy, such as in the South } \\
\text { China Sea. }\end{array}$ & $\begin{array}{l}\text { Chinese state, } \\
\text { Cambodian state. }\end{array}$ & $\begin{array}{l}\text { Chinese state, } \\
\text { Cambodian state. }\end{array}$ & $\begin{array}{l}\text { Long-term close } \\
\text { political ties between } \\
\text { China and Cambodia. }\end{array}$ & $\begin{array}{l}\text { Stable regional } \\
\text { power dynamics. }\end{array}$ & \multirow{2}{*}{$\begin{array}{l}\text { Political alliance at the top } \\
\text { level crushes much opposition } \\
\text { or concerns at the local level. } \\
\text { Lack of communication and } \\
\text { joint actions between } \\
\text { Sinohydro and Cambodian } \\
\text { institutions on mitigation } \\
\text { strategies and compensation } \\
\text { issues. National EIA } \\
\text { legislation not adequately } \\
\text { enforced and implemented. }\end{array}$} & $\begin{array}{l}\text { Poor local people are } \\
\text { marginalised even further } \\
\text { by the dam. }\end{array}$ \\
\hline & $\begin{array}{l}\text { With regards to environmental } \\
\text { governance for dams, } \\
\text { Cambodian Environmental } \\
\text { Impact Assessment (EIA) } \\
\text { legislation requires to have } \\
\text { proper EIA procedures and } \\
\text { mitigation plans in place to } \\
\text { safeguard the environment. }\end{array}$ & $\begin{array}{l}\text { Various Cambodian } \\
\text { ministries, most } \\
\text { importantly the } \\
\text { Ministry of } \\
\text { Environment (MoE). }\end{array}$ & $\begin{array}{l}\text { Local and national } \\
\text { environment and } \\
\text { affected communities. }\end{array}$ & $\begin{array}{l}\text { Potentially strong } \\
\text { environmental } \\
\text { protection. }\end{array}$ & $\begin{array}{l}\text { In reality the EIA } \\
\text { approval was issued } \\
7 \text { months after the dam } \\
\text { started operation. }\end{array}$ & & $\begin{array}{l}\text { Severe environmental } \\
\text { impacts, disadvantages for } \\
\text { the affected local } \\
\text { communities. }\end{array}$ \\
\hline
\end{tabular}




\subsection{Trade, Aid and Investment}

The Kamchay dam was part of a US\$600 million aid, trade, investment package (a bundled deal) to Cambodia from China ExIm Bank. The motives outlined in the institutional interviews were economic and political ties with Cambodia, saturation of the Chinese dams sector and the Chinese government's Going Out Strategy. Sinohydro is the prime beneficiary as it collects revenues for 44 years from the Cambodian government. Other beneficiaries are located in Phnom Penh and other urban areas, where the electricity is being used. The main negative impacts are being felt by the affected local communities who have livelihood losses/declines.

\subsection{Innovation}

Technology transfer of hydropower dams' hardware between China and Cambodia has happened for the Kamchay dam. The economic profit is made by the Chinese dam-builders, in reserve access to modern electricity generation infrastructure was provided to the Cambodian state. Sinohydro is thereby the innovator in large dams' technology while the Cambodian state is the recipient. These issues of innovation and technology transfer have been discussed in detail by Urban et al. 2015 [31].

\subsection{Politics}

At the bi-lateral level, the dam has contributed to close political ties between China and Cambodia. This ensures China is a powerful political ally for Cambodia and it ensures China receives support from Cambodia for its foreign policy, such as in the South China Sea. As the Kamchay dam is not only a piece of infrastructure, but has also political relevance, our fieldwork reveals that the political alliance at the top level crushes much opposition or concerns at the local level. The interviews found there is also a lack of communication and joint actions between Sinohydro and Cambodian institutions on mitigation strategies and compensation issues.

\subsection{Environmental Governance: The Role of the EIA Legislation and Lack of Proper Implementation}

In terms of environmental governance for dams, one issue worth exploring in detail is the Cambodian Environmental Impact Assessment (EIA) legislation that requires to have proper EIA procedures and mitigation plans in place to safeguard the environment. The government authorities that are responsible for dams are the Ministry of Industry, Mines and Energy (MIME), the Ministry of Water Resources and Meteorology (MOWRAM) and the Ministry of Environment (MoE). All BOT projects such as the Kamchay dam have to be approved by the Council for the Development of Cambodia (CDC) [34]. By Cambodian law, development projects such as dams are required to have an Environmental Impact Assessment (EIA) in place and approved before the dam construction begins. The main legal framework for the EIA is the Sub-decree on EIA passed by MoE in 1999. The EIA has to be approved by several ministries, including those mentioned above. MoE is primarily responsible for organising the conduction of the EIA, reviewing the report and monitoring compliance with environmental legislation [34].

As part of the Cambodian EIA legislation, every EIA needs to be approved before the construction starts and consultation with all stakeholders is required. However at the Kamchay dam official procedures for stakeholder engagement were not in place, therefore the consultation process before the dam construction was patchy and ad-hoc with little local participation. A man from Tvi Khang Cheung stated: "we have never been invited to join any meetings, but the village chief informed us". Another respondent from Bat Kbal Damrei said: "No one informed us. I just heard from other people who live in a Snam Prampir village, and they told the story from one to another". Many villagers were not invited to consultation processes and became only aware of the dam once construction had started. A man from Ou Touch reported: "Before the construction of the dam, I did not know, but I went to the forest every day, then I saw them constructing the dam". According to our interviews village chiefs were involved in the consultation process "Before the dam construction, the Chinese Company came to ask and informed us that 
they will construct the dam" (village chief in Ou Touch). However, village chiefs did not participate actively in the consultation process: "They invited me to attend a consultation at their Hydropower Company. However, we just went to listen to them"; and "during consultation the company already told us that people should find alternative jobs instead of collecting bamboo" (village chief in Ou Touch).

In addition, the Environmental Management Plan (EMP), which aims to implement mitigation measures to reduce the negative effects of the dam, was not in place until the late stages of the dam construction. It is also being reported that Sinohydro refuses to implement any mitigation measures, as confirmed by our interviews and other reports (NGO Forum, 2013). Sinohydro is said to have set aside a so-far untouched budget of US $\$ 5$ million for implementing mitigating measures, such as replanting 2000 ha of forest [35], however even high-ranking officials at the provincial Department for the Environment and the EIA office are criticising Sinohydro for its inaction as confirmed by our interviews.

The communication and decision-making process between Sinohydro and the Cambodian authorities seems rather opaque and hierarchical. The typical way of communicating is either between Sinohydro and MIME in Phnom Penh or between Sinohydro and the Kampot Provincial Governor. MIME in Phnom Penh then communicates with the Provincial Department of Mines and Energy in Kampot, whereas the communication between the Provincial Governor and the provincial authorities is less clear. The communication between Sinohydro and MoE and the provincial Department of Environment seems patchy and ad-hoc at best as there seems to be no clear routine for communication between the two organisations, despite both are based in Kampot.

The communication and decision-making process between the local population and Sinohydro is even more complicated. As mentioned before, those most affected by the dam were barely involved in pre-construction consultation processes. The local villagers have complained in various forms (petitions, mass demonstrations, filing individual complaints) against Sinohydro. Men from Tvi Khang Cheung village pointed out, "there were many complaints about the banning lof access to the bamboo forests affected by the dam]", and other villagers reported how "up to 300 people protested on one occasion at being unable to access the bamboo areas". Some were dissatisfied with the low water levels at Tuek Chhu resort and would like the dam operators to release more water from the reservoir, and others complained about not having access to electricity (see Section 3.2 for details on water and energy access by local communities). Nevertheless they had to follow a strict hierarchy addressing first the village chief, then the commune authority, then the district authority, then the provincial authority and from there on the complaints are said to be taken to the appropriate ministries in Phnom Penh (mainly MIME) who then establishes a communication with Sinohydro. This is despite Sinohydro's offices being based at the dam site, in very close proximity to the affected villages. In the future, the complaint process may be even less advantageous for the local population as it was recently reported, in relation to the Chinese-built Lower Sesan 2 dam, that Cambodia's ministers propose to handle complaints against Chinese dam-builders only in courts. However, poor rural villagers whose livelihoods have been adversely affected and who may be forced to resettle do not have the financial, human and administrative capacity to file a formal complaint at court level [30].

Moreover, according to the results of the Nvivo analysis and the selected quotes from villagers, a lack of access to natural resources such as forests, land and water, and hence a decline in people's traditional livelihoods has led to a monetisation of their lives, often without providing alternative options such as local employment and training. Bamboo collectors, fruit vendors and fishers have lost/declined livelihoods due to the dam, yet these groups of people were not considered for compensation payments. Some of the villagers, namely durian growers and other plantations growers, are positively affected by the dam. Some of them received compensation by Sinohydro for land that was lost due to construction of the dam (e.g., land that was used for building roads). Rather than compensating for the lost land, Sinohydro compensated the affected families for the lost trees. The villagers reported that a lost banana tree was compensated at US $\$ 10$, a mango tree at US $\$ 30$, a durian tree at US\$100-US\$500 depending on size and age. The durian growing families thought 
this was a fair compensation payment. Other groups of people who are directly but less affected by the dam are small holder farmers who own land, such as rice fields, that have been acquired by Sinohydro to build construction infrastructure (mainly roads) and people who live directly under the power lines (10 families). Compensation was paid to villagers who lost their rice fields, however only at US\$3 per square meter, which the villagers considered too low, as discussed above. No resettlement has taken place for those who live under the power lines and it is not clear yet how and when they will be compensated and relocated.

The analysis has showed how the society-environment relationship, which is central to the political ecology analysis, has changed since the dam construction as rural livelihoods at the dam site are closely linked to access to natural resources, which is now more limited. The analysis also highlights the role of China as a rising power, by highlighting the role Sinohydro plays for controlling the flow of the river, compensation payments and access to natural resources.

\section{Conclusions}

This paper used a Political Ecology of the Asian Drivers perspective to examine how the Kamchay dam, Cambodia's first dam, has altered the human-environment interactions of affected communities, as well as how different actors, such as Chinese dam builders and Cambodian authorities, have exerted their power over the use of natural resources. For that purpose, positive and negative impacts of the dam have been identified together with the main beneficiaries of the dam construction and those not benefitting much from the dam. While the majority of local communities have lost access to important resources without receiving proper compensation for their losses, especially in the case of NTFPs collectors, Chinese builders will receive the revenues from the construction of the dam for the next 40 years. This rises a fundamental question about the type of contract Cambodian authorities have signed with Sinohydro and how responsibilities about local impacts have been identified and assigned. Theoretically, as this project is under the BOT investment model, Sinohydro should have bigger role in stakeholder engagement with the local communities, as they have operation stewardship for the next 40 years. The absence of a local owner as exemplified in the Engineering Procurement Construction (EPC) models also means Sinohydro needs to be directly involved when it comes to consultation with the locals. However, communication between Sinohydro and governing authorities, and the people affected, has been very limited, as our analysis has demonstrated. This was mainly due to the lack of official grievance redress mechanisms and a clear allocation of responsibilities between the project developers, Sinohydro, and government authorities. The limited participation and consultation of local affected people on one side and the Chinese dam-builders and Cambodian government agencies on the other side, illustrates the unequal power relations between these various stakeholders in the physical and political environments. The lack of a clear allocation of responsibilities and limited communication between Sinohydro, government authorities and local communities is exemplified by the occurrence of flood disasters due to sudden releases of water by Sinohydro from the Kamchay dam, with little or no advance warning, causing damages to homes, crops, livestock, and farm land of downstream villages [46]. A better communication and identification of responsibilities between Chinese dam builders and Cambodian authorities in terms of compensation, consultation and mitigation of the impacts is an essential step toward reducing the vulnerability of affected people for future Chinese large dams in Cambodia built under BOT contracts.

Moreover, in Cambodia, as demonstrated by the Kamchay dam case environmental planning and management often is not properly implemented, similar to proper monitoring and evaluation system for large dams. The development of strict EIA legislations and other environmental policies, in addition to robust enforcement of social and environmental safeguard processes for large dams, such as wildlife rescue operations, afforestation measures, alternative livelihood strategies, inclusive and open participation of affected communities [47], would be of greater help to achieve a more equitable distribution of costs and benefits between the national and local scales and to overcome some of the negative social and environmental implications of large dams' development in the country. 
Acknowledgments: We would like to thank the UK Economic and Social Research Council (ESRC) for funding the project "China goes global: A comparative study of Chinese hydropower dams in Africa and Asia" (ESRC grant ref number: ES/J01320X/1).

Author Contributions: Giuseppina Siciliano, Frauke Urban, Lonn Pichdara, Sour Kim, realised the fieldwork and performed the analysis. All authors (Giuseppina Siciliano, Frauke urban, Lonn Pichdara, Sour Kim and May Tan-Mullins) contributed to the writing of the paper.

Conflicts of Interest: The authors declared no conflict of interest.

\section{References}

1. Electricity Authority of Cambodia (EAC). Report on Power Sector of the Kingdom of Cambodia; EAC: Phnom Penh, Cambodia, 2014; Available online: http://eac.gov.kh/wp-content/uploads/2015/07/report-2014en.pdf (accessed on 6 June 2016).

2. ASEAN Centre for Energy. Electrical Tariffs in ASEAN Member Countries; ASEAN Center for Energy: South Jakarta, Indonesia, 2014; Available online: http:/ /asean.bicaraenergi.com/2014/05/asean-electricity-tariff2014/ (accessed on 6 June 2016).

3. International Energy Agency (IEA). World Energy Outlook. 2013. Available online: http://www.iea.org/ statistics / (accessed on 19 November 2015).

4. Government of Cambodia. National Strategic Development Plan 2009-2013 (NSDP). 2010; Available online: http://www.gafspfund.org/sites/gafspfund.org/files/Documents/Cambodia_6_of_16_ STRATEGY_National_Strategic_\%20Development_Plan.NSDP_0.pdf (accessed on 19 November 2015).

5. International Rivers. Letter to SGS Re Kamchay Hydroelectric BOT Project (Cambodia). Available online: http:/ / www.internationalrivers.org/resources/letter-to-sgs-re-kamchay-hydroelectric-bot-projectcambodia-7395 (accessed on 19 November 2015).

6. Open Development Cambodia (ODC). Briefing on Hydropower. Available online: http://www. opendevelopmentcambodia.net/briefing/hydropower/ (accessed on 19 November 2015).

7. Intergovernmental Panel on Climate Change (IPCC). Renewable Energy Sources and Climate Change Mitigation. Summary for Policy-Makers and Technical Summary. Available online: http:/ /www.ipcc.ch/ pdf/special-reports/srren/SRREN_FD_SPM_final.pdf (accessed on 14 September 2015).

8. Billington, D.P.; Donald, C.J. Big Dams of the New Deal Era: A Confluence of Engineering and Politics, 1st ed.; University of Oklahoma Press: Norman, OK, USA, 2006; p. 369.

9. Ansar, A.; Flyvbjerg, B.; Budzier, A.; Lunn, D. Should we build more large dams? The actual costs of hydropower megaproject development. Energy Policy 2014, 69, 43-56. [CrossRef]

10. Sovacool, B.K.; Nugent, D.; Gilbert, A. Construction Cost Overruns and Electricity Infrastructure: An Unavoidable Risk? Electr. J. 2014, 27, 112-120. [CrossRef]

11. Brown, P.H.; Tullos, D.; Tilt, B.; Magee, D.; Wolf, A.T. Modeling the costs and benefits of dam construction from a multidisciplinary perspective. J. Environ. Manag. 2009, 90, 303-311. [CrossRef] [PubMed]

12. Chen, S.; Chen, B.; Fath, B.D. Assessing the cumulative environmental impact of hydropower construction on river systems based on energy network model. Renew. Sustain. Energy Rev. 2015, 42, 78-92. [CrossRef]

13. Tullos, D.D.; Foster-Moore, E.; Magee, D.; Tilt, B.; Wolf, A.T.; Schmitt, E.; Gassert, F.; Kibler, K. Biophysical, socioeconomic, and geopolitical vulnerabilities to Hydropower development on the $\mathrm{Nu}$ River, China. Ecol. Soc. 2013, 18, 16. [CrossRef]

14. McDonald-Wilmsen, B.; Webber, M. Dams and displacement: Raising the standards and broadening the research agenda. Water Altern. 2010, 3, 142-161.

15. Sovacool, B.K.; Bulan, L.C. Behind an ambitious megaproject in Asia: The history and implications of the Bakun hydroelectric dam in Borneo. Energy Policy 2011, 39, 4842-4859. [CrossRef]

16. Tilt, B.; Braun, Y.; He, D. Social impacts of large dam projects: A comparison of international case studies and implications for best practice. J. Environ. Manag. 2009, 90, 249-257. [CrossRef] [PubMed]

17. Bosshard, P. China Dams the World. Wold Policy J. 2009, 26, 43-51. [CrossRef]

18. McDonald, K.; Bosshard, P.; Brewer, N. Exporting dams: China's hydropower industry goes global. J. Environ. Manag. 2009, 90, 294-302. [CrossRef] [PubMed]

19. International Rivers. China Overseas Dams List. Available online: https://www.internationalrivers.org/ resources/china-overseas-dams-list-3611 (accessed on 6 June 2016). 
20. Biggs, E.M.; Bruce, E.; Boruff, B.; Duncan, J.M.A.; Horsley, J.; Pauli, N.; McNeill, K.; Neef, A.; Van Ogtrop, F.; Curnow, J.; et al. Sustainable development and the water-energy-food nexus: A perspective on livelihoods. Environ. Sci. Policy 2015, 54, 389-397. [CrossRef]

21. Bryant, P. The Political Economy of Soil Erosion in Developing Countries, 1st ed.; Longman: London, UK, 1985; p. 188.

22. Bryant, R.; Bailey, S. Third World Political Ecology, 1st ed.; Routledge: London, UK, 1997; p. 256.

23. Perreault, T.; Bridgee, G.; McCarthy, J. The Routledge Handbook of Political Ecology, 1st ed.; Routledge: New York, NY, USA, 2015; p. 646.

24. Tan-Mullins, M. The State and Its Agencies in Coastal Resources Management: The Political Ecology of Fisheries Management in Pattani, Southern Thailand. Singap. J. Trop. Geogr. 2007, 28, 348-361. [CrossRef]

25. Wolf, E. Ownership and Political Ecology. Anthropol. Q. 1972, 45, 201-205. [CrossRef]

26. Humphrey, J.; Messner, D. China and India as Emerging Global Governance Actors: Challenges for Developing and Developed Countries. IDS Bull. 2006, 37, 107-114. [CrossRef]

27. Schmitz, H. Asian Drivers: Typologies and Questions. IDS Bull. 2006, 37, 54-61. [CrossRef]

28. Kaplinsky, R.; Messner, D. The impact of Asian drivers on the developing world. World Dev. 2008, 36, 197-209. [CrossRef]

29. Siciliano, G.; Frauke, U.; Kim, S.; Lonn, P.D. Hydropower, Social Priorities and the Rural-Urban Development Divide: The Case of Large Dams in Cambodia. Energy Policy 2015, 89, 273-285. [CrossRef]

30. Urban, F.; Nordensvärd, J.; Wang, Y.; Khatri, D.; Mohan, G. China and the African Oil Sector: Channels of Engagement, Motives, Actors and Impacts; IDS Rising Powers Working Paper; Institute of Development Studies: Brighton, UK, 2011; Volume 2.

31. Urban, F.; Siciliano, G.; Sour, K.; Lonn, P.D.; Tan-Mullins, M.; Mang, G. South-South Technology Transfer of Low-Carbon Innovation: Large Chinese Hydropower Dams in Cambodia. Sustain. Dev. 2015, 23, 232-244. [CrossRef]

32. NGO Forum Cambodia. The Kamchay Hydropower Dam: An Assessment of the Dam's Impacts on Local Communities and the Environment; NGO Forum: Phnom Penh, Cambodia, 2013.

33. International Rivers. Hydropower Dams in Cambodia. Available online: http://www.internationalrivers. org/campaigns/cambodia (accessed on 19 November 2015).

34. Grimsditch, M. China's Investments in Hydropower in the Mekong Region: The Kamchay Hydropower Dam, Kampot, Cambodia. 2012. Available online: http://www.bicusa.org/wp-content/uploads/2013/02/ Case+Study+-+China+Investments+in+Cambodia+FINAL+2.pdf (accessed on 19 November 2015).

35. Middleton, C. Cambodia's Hydropower Development and China's Involvement; Rivers Coalition Cambodia: Phnom Penh, Cambodia, 2008.

36. Global Energy Observatory (GEO). Kamchay Dam. 2014. Available online: http://globalenergyobservatory. org/geoid/43061 (accessed on 6 September 2016).

37. Sanitation, Agriculture, Water and Agronomy in Cambodia (SAWAC). Environmental and Social Impact Assessment (ESIA): Kamchay Hydroelectric Project in Kampot Province; SAWAC: Phnom Penh, Cambodia, 2011.

38. Mohan, G. China in Africa: A Review Essay. Rev. Afr. Political Econ. 2008, 35, 155-173. [CrossRef]

39. Jacques, M. When China Rules the World: The Rise of the Middle Kingdom and the End of the Western World, 1st ed.; Allen Lane: London, UK, 2009; p. 778.

40. Alden, C.; Large, D.; de Oliveira, R.S. China Returns to Africa: A Rising Power and a Continent Embrace, 1st ed.; HURST Publishers Ltd.: London, UK, 2008; p. 382.

41. Brautigam, D. The Dragon's Gift: The Real Story of China in Africa, 1st ed.; Oxford University Press: Oxford, UK, 2009; p. 416.

42. Urban, F.; Mohan, G.; Cook, S. China as a new shaper of international development: The environmental implications. Environ. Dev. Sustain. 2013, 15, 257-263. [CrossRef]

43. Wolcott, H. Writing up Qualitative Research, 3rd ed.; Sage: London, UK, 1990; p. 208.

44. Wiles, R.; Heath, S.; Crow, G.; Charles, V. Informed Consent in Social Research: A Literature Review. ESRC National Centre for Research Methods NCRM Methods Review Papers NCRM/001. 2005. Available online: http:/ / eprints.ncrm.ac.uk/85/1/MethodsReviewPaperNCRM-001.pdf (accessed on 19 November 2015).

45. Yin, R.K. Case Study Research: Design and Methods, 5th ed.; Sage: Thousand Oaks, CA, USA, 2014; p. 312. 
46. The Cambodia Daily. Hundreds Flee Homes after Dam Gates Opened. 2015. Available online: https: //www.cambodiadaily.com/news/hundreds-flee-homes-after-dam-gates-opened-94476/ (accessed on 9 September 2016).

47. United Nations Environment Programme (UNEP). Dams and Development. A New Framework for Decision Making; Report of the World Commission on Dams; Earthscan: London, UK; Sterling, VA, USA, 2000; p. 404. Available online: http:/ / www.unep.org/dams/WCD/ (accessed on 6 June 2016).

(C) 2016 by the authors; licensee MDPI, Basel, Switzerland. This article is an open access article distributed under the terms and conditions of the Creative Commons Attribution (CC-BY) license (http:/ / creativecommons.org/licenses/by/4.0/). 